equivalent post in psychiatry for at least five years.

The following criteria are used for the appointment of Examiners to either Board:

(a) must be registered for CPD;

(b) must be practising in an appropriate clinical area of psychiatry and seeing patients on a regular basis;

(c) must have had some experience of teaching at a postgraduate level;

(d) must have current or recent experience of training doctors undergoing basic level training in psychiatry.

Examiners can only be nominated by one of the following:

(a) member of the Court of Electors;

(b) a Professor of Psychiatry;

(c) a Regional Adviser;

(d) Chairmen of the Divisions, Faculties and Sections of the College:

(e) Chairmen of Regional Training Committees.
A Nomination Form has to be completed and signed by an individual from one of the categories listed above. Forms are avallable from: Assistant to the Head of Examination Services, The Examination Services Department, Royal College of Psychiatrists, 17 Belgrave Square, London SW1X 8PG. Tel: 0171235 2351, ext. 252.

The nominee should attach a full Curriculum Vitae to the form, which should provide the information set out in the criteria listed above.

The form and the Curriculum Vitae should be returned to the Chief Examiner at the address above.

Eligible nominations are then considered by the Court of Electors.

The Court of Electors decides which Examiners are to be appointed to each Board.

S. P. Tyrer, Chief Examiner, Royal College of Psychiatrists, 17 Belgrave Square, London SWIX 8PG

\title{
Elections to the General Medical Council
}

Psychiatrists have a crucial role to play in assisting the work of the General Medical Council, particularly in relation to its Health Procedures. There are, at present, three psychiatrists on the General Medical Council, out of a total of 102.

Voting papers for election to the General Medical Council will be dispatched to registered doctors in England, Scotland, Wales and Northern Ireland in May 1999. You may wish to know that the following psychiatrists will be standing for election.

Dr Mark Aveline, Consultant Psychotherapist, Nottingham Psychotherapy Unit.

Dr R. N. Chitty, Consultant Psychiatrist, West Cheshire Hospital.

Dr Anwar E1-Komy, Consultant Psychiatrist, Forston Clinic, Dorchester.

Dr Doug Fowlie, Consultant Psychiatrist and Honorary Clinical Senior Lecturer, Royal Cornhill Hospital, Aberdeen.
Professor Bamid Ghodse, Professor of Psychiatry. St George's Medical School, London.

Dr Pearl Eettiaratchy, Consultant Psychiatrist in Old Age Psychiatry, Winchester (currently a member of the General Medical Council - eligible for re-election).

Dr Andrew MacAulay, Consultant Psychiatrist, Wrexham Park Hospital.

Dr J. McDonald, Consultant Psychiatrist, Queen Elizabeth Hospital, Gateshead.

Stephen O'Brien, Clinical Director, University Hospital, Aintree.

Professor Andrew Sims, Professor of Psychiatry, University of Leeds (currently a member of the General Medical Council-eligible for reelection).

Dr Paul Srinivasan, Consultant Psychiatrist, St George's Hospital, Stafford.

Vanessa Cameron, The Secretary, Royal College of Psychiatrists, 17 Belgrave Square, London SW1X 8PG 